\title{
Physical and Organoleptic Properties of Cookies Produced with Date Fruit Pulp, Toasted Watermelon Seed and Wheat Flour Composite
}

\author{
A. I. Peter-Ikechukwu, N. O. Kabuo, A. E. Uzoukwu, M. N. Chukwu, and C. Ogazi
}

\begin{abstract}
Composite flour of different ratios were produced from wheat, date fruit pulp and toasted watermelon seeds. Cookies of various blends $(\mathrm{CHU}=\mathbf{1 0 0} \%$ wheat Flour without fat and sugar; CHUY $=100 \%$ wheat flour with sugar and fat; CHUY $_{1}=90 \%$ : 5\%:5\%; $\quad$ CHUY $_{2}=\quad 80 \%: 10 \%: 10 \%$; CHUY $_{3}=70 \%: 15 \%: 15 \% ;$ CHUY $_{4}=60 \%: 20 \%: 20 \%$ wheat flour: toasted watermelon seed: date fruit pulp flour respectively) were produced. The physical and organoleptic properties of the cookies were determined and Mean values of the triplicate data were subjected to One-Way ANOVA. The means were separated using Fishers' test $(\mathbf{p} \leq \mathbf{0 . 0 5})$. CHUY $\mathrm{C}_{3}$ was preferred in physical properties: spread ratio (3.95), thickness $(11.65 \mathrm{~mm})$, diameter $(45.66 \mathrm{~mm})$ and weight $(7.30 \mathrm{~g})$. The organoleptic qualities of CHUY: aroma (7.15), Colour (7.45), taste (7.55), texture (7.45), crispness (7.35) and overall acceptability (7.35) were better. However, no significant $(p \leq 0.05)$ difference was observed in overall acceptability. Efforts should be geared towards the commercial production of this cookies as well as suitable packaging material for it.
\end{abstract}

Index Terms-Flour, Blends, Spread Ratio, Crispness, Aroma, Diameter.

\section{INTRODUCTION}

Cookies is a form of confectionary products usually dried to a low moisture content with softer mouth consistency. They are ready-to-eat food products containing digestive and dietary nutrients of vital importance. The main ingredients of cookies include wheat flour, fat (margarine), sugar, water, while other ingredients such as milk, fat, aerating agent, emulsifier, flavor, and colour can be included (Ajibola et al., 2015).

Wheat grain (Triticum spp) is of the family "poaceae". Wheat structure is made up of bran (the outer layer), germ and endosperm. Nutritionally, wheat consists of dietary fibre $(0.5 \%)$, mineral content $(7.2 \%)$, protein $(25 \%)$ and fat $(8-$ 13\%) (Peter-Ikechukwu et al., 2019.). Wheat grains are staple food used to make flour, for leavened, flat and steamed breads, cookies, cakes, breakfast, cereal, pasta, noodles and for fermentation to make beer and other alcoholic beverages. Wheat remains the choice flour for baked products because of its gluten content which other cereals lack (Ishiwu et al., 2014) and improved the baking quality (Kumar et al., 2011; Peter-Ikechukwu et al., 2019).

Published on April 23, 2020.

A. I. Peter-Ikechukwu, N O. Kabuo, A. E. Uzoukwu, and C. Ogazi are with the Department of Food Science and Technology, Federal University of Technology, Owerri, Nigeria.

M. N. Chukwu (Corresponding Author) is with Department of Food Technology, Abia State Polytechnic, Aba, Abia State, Nigeria. (e-mail: mchukwu61@gmail.com)
Watermelon (Citrillus lanatus), is a typical fruit from the Crucurbitaceae. It contains seeds which have been found effective in baking (Nasir and Abufoul, 2004). The seeds are flat brown with a nutty and nice taste and have much bigger food value than the water melon pulp (Erhirhie and Ekene, 2013). The seeds have high fat content $(50 \%)$ and protein content of $(35 \%)$ and are also rich in Vitamin A, C, and minerals example potassium (El-Adawy and Taha, 2001). In addition, they are rich source of fiber (39.09-43.28\%) (Betty et al., 2016) which is a desirable quality in production of cookies. This is because fibre aids in bowel movement and cleaning of the colon when consumed in the body. There is considerable amount of phenols in water melon seeds. Phenols have ability to scavenge free radicals and neutralize their effects thereby preventing cancer and other cardiovascular diseases (Betty et al, 2016).

Date palm fruit (Phonenix dactylifera) is locally known as "debino" in Hausa language from the family of Aracaceae (Hamza et al., 2014), is a known fruit for its sugary taste. The fruit is a drupe in which the outer fleshy part consists of the pulp and the pericarp surrounding a shell of hard endocarp with the seed inside (Farheena et al., 2015). According to Dadaet al. (2012), date palm fruits consist of more than $70 \%$ sugar mainly glucose and fructose. It is high in energy value thus making it an ideal replacement for sugar (sucrose) in the cookie recipe. It is also of great nutritional benefit because it reduces the risk of increasing blood sugar level of diabetic patients, and rich in fiber (Hamza et al., 2014), antioxidants, and flavonoids such as beta carotene, lutenin and zeaxanthin. It is also an excellent source of iron, copper, calcium, vitamin A and $\mathrm{B}_{2}$ (Dada et al., 2012; Farheena et al., 2015).

Cookies can be enriched and fortified however to meet specific nutritional needs of consumers. This is important because food industry is primarily driven by consumer's health trends and it helps to reduce the risk of these nutrition- related chronic diseases. The consumption of fat and sugar has been found to be associated with health problems such as obesity, diabetes and other coronary heart disease (Boobier et al., 2006).

The main objective of this research is the substitution of sugar and fat with date palm fruit pulp and toasted water melon seed respectively in the production of cookies. The specific objectives are the formulation of composite flour blends of wheat flour, toasted water melon seed flour and date palm flour and the determination of physical and organoleptic properties of the cookies samples.

Success of this work will lead to production of cookies that will proffer solution to the nutritional needs of those 
with some health challenges like diabetes, obesity and heartrelated diseases, as it will give them the opportunity to enjoy cookies like everyone else. Therefore, fortifying cookies with toasted water melon seed and date palm pulp will not only be an ideal snack for people with these health challenges only, but will also improve the nutritional qualities of cookies for the general public.

\section{MAterials AND Methods}

\section{A. Collection of Materials}

The dried date palm fruits and Water melon fruits were purchased at Douglas Road (Ama Hausa) and Relief market Owerri respectively. Other ingredients were wheat flour, milk flavour, egg, margarine (fat), baking powder, sugar, salt, flavouring (vanilla) were also obtained from Owerri Main market, Imo State, Nigeria.

\section{B. Preparation of Toasted Water Melon Seed Flour}

The modified method of Ubhor and Akobundu (2009) was used.Toasted watermelon seed flour was prepared by deseeding water melon pods, the seeds were then washed with portable water, drained and sun dried. With the help of a regulated oven, the seeds were toasted at a temperature of $130^{\circ} \mathrm{C}$ for 20 minutes. The seeds were then milled after cooling and sieved through $60 \mathrm{~mm}$ mesh sieve to obtain a fine flour (Fig. 1).

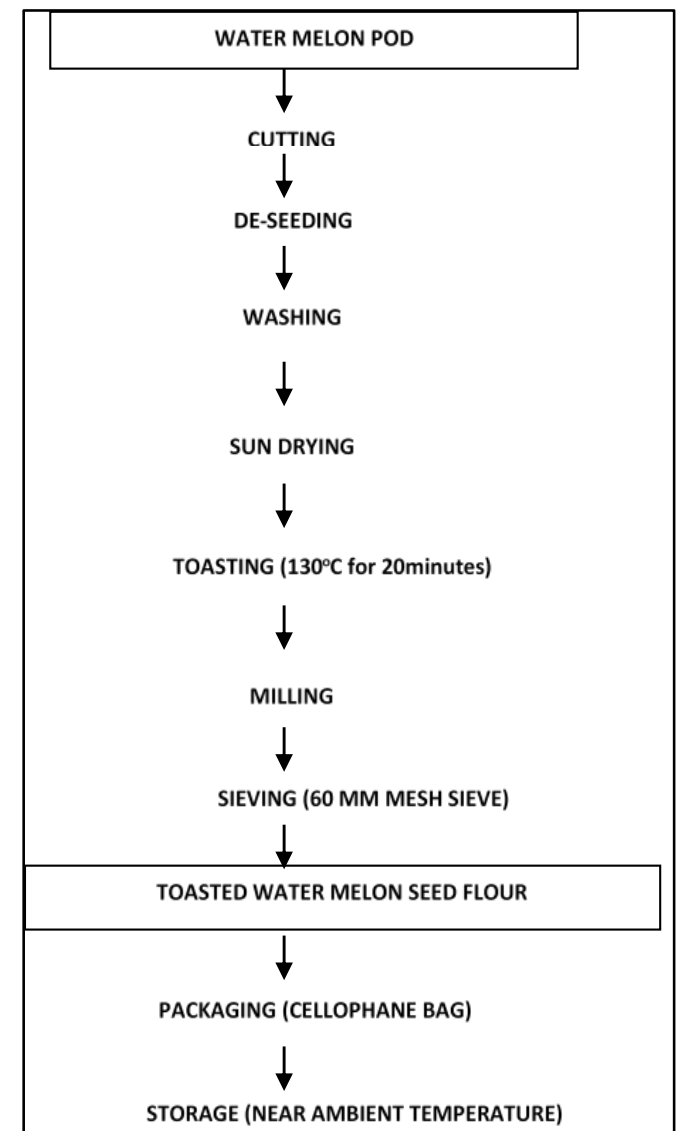

Fig. 1. Flow diagram of toasted watermelon seed flour produced

\section{Preparation of Date Palm Fruit Pulp (DPFP)}

The date palm fruit pulp four was produced by first washing the date palm fruit with water to remove adhering dirt followed by deseeding of the fruit manually. The fleshy pulp was cut into small pieces with the aid of a knife. The pulp with pericarp was then oven dried at $75^{\circ} \mathrm{C}$ for 6 hours and subsequently milled using hand milling machine and sieved through $0.35 \mathrm{~mm}$ mesh sieve to obtain a fine homogenous particle and packaged for use as shown in Fig. 2.

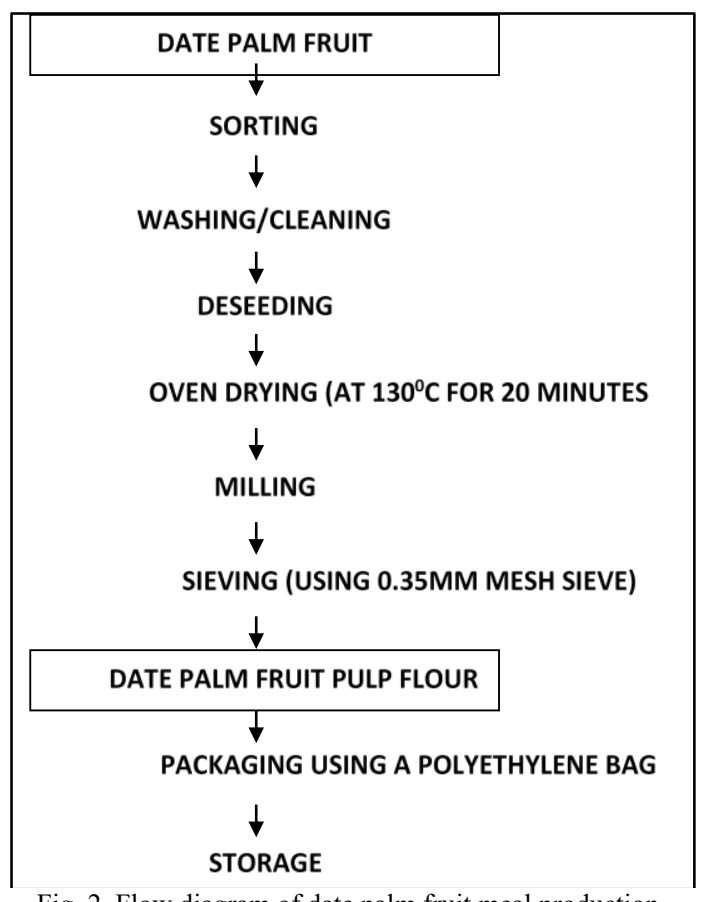

Fig. 2. Flow diagram of date palm fruit meal production

\section{Cookies Flour Formulation Ratios}

The composite flours for the cookies were formulated using the modified method by Olapade et.al. (2014) with wheat flour, date palm fruit pulp meal (DPFP) and toasted water melon seed meal in the following ratios 90:5:5, $80: 10: 10,70: 15: 15,60: 20: 20,50: 25: 25$. The controls were: $100 \%$ wheat with sugar and fat and 100\% flour without sugar and fat.

TABLE I: RATIOS OF COMPOSITE FLOUR

\begin{tabular}{cccc}
\hline \hline $\begin{array}{l}\text { Blends } \\
\text { (Flour) }\end{array}$ & $\begin{array}{c}\text { Wheat } \\
\text { Flour }\end{array}$ & $\begin{array}{c}\text { Toasted watermelon } \\
\text { seed }\end{array}$ & $\begin{array}{c}\text { Date palm fruit } \\
\text { flour }\end{array}$ \\
\hline CHUY $_{1}$ & 90 & 5 & 5 \\
\hline CHUY $_{2}$ & 80 & 10 & 10 \\
\hline CHUY $_{3}$ & 70 & 15 & 15 \\
\hline CHUY $_{4}$ & 60 & 20 & 20 \\
\hline CHUY $_{5}$ & 50 & 25 & 25 \\
\hline \hline
\end{tabular}

Two controls $(\mathrm{CHUY})=100 \%$ wheat flour with sugar and margarine, and $(\mathrm{CHU})=100 \%$ wheat flour without sugar and fat (margarine).

\section{E. Production of Cookies with the Formulated Composite Flour Blends}

The ingredients (wheat flour, toasted watermelon seed meal and date palm fruit meal were measured into a bowl using the rubbing method (Peter-Ikechukwu et al., 2016), milk flavour was added and mixed for 30 minutes. In a separate bowl, egg and water were mixed and added to the flour based mixture and kneaded into a dough. The dough was rolled and flattened into a uniform thickness of about $3.5 \mathrm{~mm}$ before cutting out into shapes using a hand cutter. The cut out dough was baked at $150^{\circ} \mathrm{C}$ for $30 \mathrm{mins}$ in the oven. After baking, the cookies were cooled at room temperature, packaged in low density polyethylene (LDPE) 
bags and sealed in a plastic transparent container. The process is shown in Fig. 3.

WHEAT FLOUR, TOASTED WATERMELON SEED FLOUR, DATE

MIXING (COMPOSITE FLOUR, Milk Flavour, Baking Powder) ADDITION OF SUGAR AND FAT (FOR CONTROL)

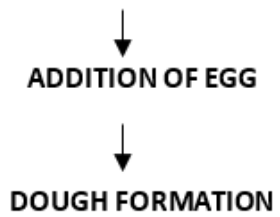

ROLLING OF DOUGH

CUTTING OF DOUGH

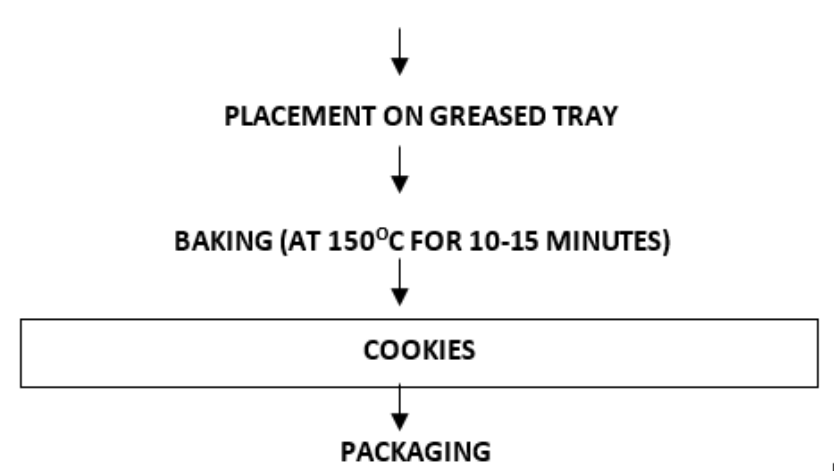

Fig. 3. Flow diagram showing the production of cookies

\section{F. Evaluation of the Physical Properties of Cookies}

1) Determination of diameter and weight of cookies

The modified method according to Ayo et al. (2007) was used to determine the diameter and weight of cookie.The weight of the baked cookies was determined by weighing each cookie unit on electronic weighing balance. The cookies unit was randomly selected and weighed severally and the average time taken. The cookies diameter was determined by measuring each cookies unit randomly picked using a venier caliper, and the average taken.

\section{2) Determination of cookie spread ratio}

The spread ratio was determined using the method of Gomez et al. (2007). Three rows of well-formed cookies were made and the height measured. Also, the same were arranged horizontally edge to edge and sum diameter measured. The spread ratio was calculated as diameter per height (McWatter et al., 2003).

\section{3) Determination of thickness of cookies}

The method according to McWatteret al. (2003) was used. The thickness of cookies was measured using a Venier caliper which was placed horizontally across the cookies, followed by duplicate readings.

\section{G. Sensory Evaluation}

The organoleptic properties (taste, color, texture, aroma and overall acceptability/acceptance) of the cookies were assessed by 20 -member panelists screened among staff and students, who were instructed regarding the evaluation procedures in both written and verbal formats prior to the evaluation of the cookies. Each panelist was given the cookie sample to taste and compare. A 9-point hedonic scale was used where 9 represented "like extremely", 5 represented neither like nor dislike and 1 represented dislike extremely (Peter-Ikechukwu et al., 2019).

\section{H. Statistical Analysis}

Triplicate data obtained were subjected to statistical analysis using SPSS software of version 21. Mean values were determined and One-Way ANOVA was done as well as Fisher's Least Significant Difference was used for the separation of the means at $(\mathrm{p} \leq 0.05)$ (Chukwu et al., 2019).

\section{RESUlTS AND DisCUSSION}

\section{A. Physical Properties of the Cookies Produced from} Different Flour Blends

The physical properties of the cookies samples are shown in the Table II.

TABLE II: THE PHYSICAL PROPERTIES OF COOKIES PRODUCED FROM DIFFERENT FLOUR BLENDS

\begin{tabular}{|c|c|c|c|c|}
\hline Samples & $\begin{array}{c}\text { Spread } \\
\text { Ratio(Sr) }\end{array}$ & Thickness(Mm) & Diameter(Mm) & Weight $(\mathrm{G})$ \\
\hline CHUY1 & $\begin{array}{l}2.92 \\
\pm 0.05^{\text {ab }}\end{array}$ & $14.51 \pm 0.22^{\mathrm{b}}$ & $40.53 \pm 0.16^{\mathrm{ab}}$ & $7.00 \pm 1.85^{\mathrm{b}}$ \\
\hline CHUY2 & $2.44 \pm 0.54^{\mathrm{b}}$ & $14.91 \pm 0.700^{\mathrm{b}}$ & $40.03 \pm 5.41^{\mathrm{ab}}$ & $7.25 \pm 1.73^{\mathrm{b}}$ \\
\hline CHUY3 & $3.95 \pm 0.03^{\mathrm{a}}$ & $11.65 \pm 1.44^{\mathrm{c}}$ & $45.66 \pm 1.70^{\mathrm{a}}$ & $7.30 \pm 1.22^{\mathrm{b}}$ \\
\hline CHUY4 & $\begin{array}{l}3.05 \pm \\
0.06^{\mathrm{ab}}\end{array}$ & $16.39 \pm 1.50^{\mathrm{ab}}$ & $44.26 \pm 156^{\mathrm{ab}}$ & $7.38 \pm 1.37^{\mathrm{b}}$ \\
\hline CHUY5 & $\begin{array}{l}3.49 \pm \\
0.53^{\mathrm{ab}}\end{array}$ & $17.82 \pm 1.15^{\mathrm{a}}$ & $39.28 \pm 0.73^{b}$ & $7.40 \pm 0.28^{b}$ \\
\hline CHUY & $3.19 \pm 0.13^{\mathrm{ab}}$ & $13.83 \pm 0.15^{\mathrm{bc}}$ & $44.02 \pm 1.41^{\mathrm{ab}}$ & $8.94 \pm 2.10^{\mathrm{a}}$ \\
\hline CHU & $2.28 \pm 0.19^{\mathrm{c}}$ & $13.90 \pm 0.25^{\mathrm{bc}}$ & $40.25 \pm 0.66^{\mathrm{ab}}$ & $7.03 \pm 0.28^{b}$ \\
\hline LSD & 0.71 & 2.24 & 5.48 & 3.42 \\
\hline
\end{tabular}

Means of duplicate determination. Mean with the same super subscripts within a column are not significantly different $(\mathrm{p} \leq 0.05)$

Keys:

$\mathrm{CHU}=100 \%$ wheat Flour without fat and sugar

CHUY $=100 \%$ wheat flour with sugar and fat

$\mathrm{CHUY}_{1}=90 \%$ wheat flour-to- $5 \%$ of toasted watermelon seed flour-to- $5 \%$ date palm pulp

$\mathrm{CHUY}_{2}=80 \%$ wheat flour-to- $10 \%$ toasted watermelon seed flour-to $10 \%$ date palm pulp

$\mathrm{CHUY}_{3}=70 \%$ wheat flour-to- $15 \%$-toasted watermelon seed flour-to- $15 \%$ date palm pulp

$\mathrm{CHUY}_{4}=60 \%$ wheat flour-to- $20 \%$-toasted watermelon seed flour-to- $20 \%$ date palm pulp

$\mathrm{CHUY}_{5}=50 \%$ wheat flour-to $25 \%$ toasted water melon seed flour-to- $25 \%$ date palm pulp

\section{1) Spread ratio of Cookies Produced from Different Flour Blends}

The spread ratio was found to be highest in $\mathrm{CHUY}_{3}$ (3.95) while CHU (2.28) had the least. Sample $\mathrm{CHUY}_{3}(70: 15: 15)$ was significantly different $\mathrm{p} \leq 0.05$ from the rest of the cookies. This could be as a result of dough viscosity of the different flour blends. According to Miller et al. (1997), spread ratio is restricted by dough viscosity as dough viscosity lowers spread ratio. Cookies having the highest spread ratio are considered a desirable quality attribute by consumers. 


\section{2) Thickness of Cookies Produced from Different Flour} Blends

The thickness and the spread ratio have an inverse relationship. $\mathrm{CHUY}_{3}(70: 15: 15)$ had the highest value on the spread ratio (3.95) and the least value in the thickness (11.65) of the cookies. This is in an agreement with Chinma and Gernah (2007) who observed similar trend in cookies produced from cassava and soya/mango composite flour and attributed it to the hydrophilic nature of the flour used for the product.

\section{3) Diameter of Cookies Produced from Different Flour Blends}

$\mathrm{CHUY}_{3} \quad(70: 15: 15)$ was found to be the highest $(45.66 \mathrm{~mm})$ and the least diameter of $39.2 \mathrm{~mm}$ in $\mathrm{CHUY}_{5}$ $(50: 25: 25)$. The cookies diameter increased with increase in proportion of date palm fruit pulp.

\section{4) Weight of Cookies Produced from Different Flour Blends}

The weight of cookies was found to be highest $(8.94 \mathrm{~mm})$ in sample CHUY (100\% wheat with fat and sugar) while the least was $\mathrm{CHUY}_{1}$ (90:5:5) with 7.00mm, although there was no significant difference among the cookies samples, and with the negative control CHU (100\% wheat flour without fat and sugar). The increase in weight of the cookies (CHUY) was due to fat inclusion (in the control).

\section{B. Organoleptic Properties of Cookies Produced from Different Flour Blends}

The sensory evaluation scores of the cookies samples are shown in Table III.

TABLE III: THE ORGANOLEPTIC PROPERTIES OF COOKIES PRODUCED FROM DIFFERENT FLOUR BLENDS

\begin{tabular}{lllllll}
\multicolumn{7}{c}{ FROM DIFFERENT FLOUR BLENS } \\
& Aroma & Colour & Taste & Texture & $\begin{array}{l}\text { Crispne } \\
\text { ss }\end{array}$ & $\begin{array}{l}\text { Overall } \\
\text { Acceptab } \\
\text { ility }\end{array}$ \\
\hline CHU & $6.10 \pm 0$. & $6.35 \pm 0$. & $6.45 \pm 1$. & $6.35 \pm 0$. & $6.55 \pm 0$. & $6.55 \pm 0.6$ \\
Y1 & $97^{\mathrm{b}}$ & $81^{\mathrm{a}}$ & $09^{\mathrm{b}}$ & $81^{\mathrm{b}}$ & $61^{\mathrm{ab}}$ & $0^{\mathrm{b}}$ \\
\hline CHU & $6.15 \pm 1$. & $6.45 \pm 0$. & $6.45 \pm 1$. & $6.45 \pm 0$. & $6.45 \pm 0$. & $6.45 \pm 0.8$ \\
Y2 & $08^{\mathrm{b}}$ & $99^{\mathrm{a}}$ & $09^{\mathrm{b}}$ & $99^{\mathrm{b}}$ & $83^{\mathrm{ab}}$ & $3^{\mathrm{b}}$ \\
\hline CHU & $6.52 \pm 0$. & $7.30 \pm 0$. & $7.10 \pm 1$. & $6.30 \pm 0$. & $7.15 \pm 0$. & $7.15 \pm 0.7$ \\
Y3 & $69^{\mathrm{b}}$ & $57^{\mathrm{a}}$ & $25^{\mathrm{b}}$ & $57^{\mathrm{b}}$ & $75^{\mathrm{a}}$ & $5^{\mathrm{a}}$ \\
\hline CHU & $6.80 \pm 1$. & $6.10 \pm 0$. & $6.00 \pm 1$. & $6.10 \pm 0$. & $6.35 \pm 0$. & $6.35 \pm 0.8$ \\
Y4 & $15^{\mathrm{b}}$ & $97^{\mathrm{a}}$ & $21^{\mathrm{b}}$ & $97^{\mathrm{b}}$ & $88^{\mathrm{ab}}$ & $8^{\mathrm{ab}}$ \\
\hline CHU & $6.83 \pm 0$. & $5.80 \pm 1$. & $5.75 \pm 1$. & $6.80 \pm 1$. & $5.70 \pm 0$. & $5.70 \pm 0.6$ \\
Y5 & $94^{\mathrm{b}}$ & $36^{\mathrm{b}}$ & $37^{\mathrm{b}}$ & $36^{\mathrm{b}}$ & $66^{\mathrm{b}}$ & $6^{\mathrm{b}}$ \\
\hline CHU & $7.15 \pm 1$. & $7.45 \pm 0$. & $7.55 \pm 0$. & $7.45 \pm 0$. & $7.35 \pm 0$. & $7.35 \pm 0.8$ \\
Y & $18^{\mathrm{a}}$ & $83^{\mathrm{a}}$ & $67^{\mathrm{a}}$ & $82^{\mathrm{a}}$ & $81^{\mathrm{a}}$ & $1^{\mathrm{a}}$ \\
\hline CHU & $5.25 \pm 0$. & $5.75 \pm 1$. & $5.65 \pm 1$. & $5.75 \pm 1$. & $6.15 \pm 0$. & $6.15 \pm 0.8$ \\
\hline LSD & $94^{\mathrm{b}}$ & $25^{\mathrm{b}}$ & $31^{\mathrm{b}}$ & $25^{\mathrm{c}}$ & $88^{\mathrm{ab}}$ & $8^{\mathrm{ab}}$ \\
\hline \hline
\end{tabular}

Values are duplicate mean \pm standard deviation. Samples with different super subscript within the same column were significantly different Keys:

$\mathrm{CHUY}_{1}=90 \%$ wheat flour-to- $5 \%$ date palm pulp-to- $5 \%$ water melon seed flour

$\mathrm{CHUY}_{2}=80 \%$ wheat flour-to- $10 \%$ date palm pulp- to- $10 \%$ water melon seed flour

$\mathrm{CHUY}_{3}=70 \%$ wheat flour - to- $15 \%$ date palm pulp-to- $15 \%$ water melon seed flour

$\mathrm{CHUY}_{4}=60 \%$ wheat flour-to- $20 \%$ date palm pulp-to- $20 \%$ water melon seed flour

$\mathrm{CHUY}_{5}=50 \%$ wheat flour-to- $25 \%$ date palm pulp -to- $25 \%$ water melon seed flour

CHUY $=100 \%$ wheat flour with fat and sugar

$\mathrm{CHU}=100 \%$ without fat and sugar

\section{1) Aroma of Cookies Produced from Different Flour} Blends

The scores for aroma of the cookies ranged from 5.20 $\left(\mathrm{CHUY}_{5}\right)$ to $6.75\left(\mathrm{CHUY}_{1}\right)$. There was no significant difference in aroma of the composite biscuit samples, however biscuits from $\mathrm{CHUY}_{1}$ (90:5:5) had the highest score (6.75) in aroma which developed from the date palm and toasted water melon addition. $\mathrm{CHUY}_{5}$ (50:25:25) had the least score (5.20) due to the strong aroma from the high percentage of toasted water melon seed. However, the aroma of cookies from composite flour was generally preferred to the control CHU (100\% wheat flour without fat and sugar).

\section{2) Colour of Cookies Produced from Different Flour Blends}

The values of colour ranged from 5.80 $\mathrm{CHUY}_{5}(50: 25: 25)$ to 7.45 CHUY (100\% wheat flour with fat and sugar). The brown colouration of the cookies was as a result of the Millard reaction of sugar associated with baked goods (Ubbor and Akobundu, 2009). The result obtained showed that the colour of cookies produced with increased substitution of toasted water melon seed and date palm were more acceptable than cookies produced without sugar and fat. (CHU).

\section{3) Taste of Cookies Produced from Different Flour Blends}

There was significant difference $\mathrm{p} \leq 0.05$ between the tastes of the cookies produced from composite flour blends. However, CHUY (100\% wheat flour with fat and sugar) had the highest rating, (7.55) followed by CHY3 (7.100). CHU $(100 \%$ without fat and sugar) was rated least (5.65). This could be due to none incorporation of sugar and fat in the cookie from sample $\mathrm{CHU}$.

\section{4) Texture of Cookies Produced from Different Flour Blends}

The control CHUY (100\% wheat flour with sugar and fat) with 7.45 was most preferred among other samples. This could be attributed to fat inclusion in cookie recipe which helped to lubricate, weaken or shorten the structure of the food components. This shows that fat plays a major role in the textural characteristics of baked product (Hasmadi and Sandra, 2014), and provides the food products with desirable textural properties. However, there was no significant difference in the texture of the cookies generally.

\section{5) Crispness of Cookies Produced from Different Flour Blends}

Crispness is a desired quality that determines consumers' purchases of any cookies. The addition of date palm pulp and water melon seed flour had varying effects in the crispness of the cookies samples. However no significant difference existed between CHUY (100\% wheat flour with fat and sugar) and sample $\mathrm{CHUY}_{3}$ (70:15:15). This showed that substitution with water melon seed and date palm flours up to $15 \%$ gave a comparable result with the control.

\section{6) Overall acceptability}

The overall acceptability of the cookies showed that CHUY (100\% wheat flour with sugar and fat) and $\mathrm{CHUY}_{3}(70: 15: 15)$ were acceptable by the panelist. However, the inclusion of toasted water melon seed and date 
palm fruit pulp up to $15 \%$ respectively yielded a positive result.

\section{CONCLUSION}

The use of date palm fruit pulp and toasted water melon seed as sugar and fat substitutes respectively in the cookies production improved the physical and organoleptic properties of the cookies. The physical properties such as cookies spread ratio, thickness, diameter and weight were affected significantly, when compared to the control. The organoleptic characteristics of $\mathrm{CHUY}_{3}$ had overall acceptability in all the parameters tested. This showed that incorporation of toasted water melon seed and date palm fruit pulp up to $15 \%$ level respectively, will produce cookies that could be acceptable by the consumers and thus help to proffer solution to some health challenges.

\section{RECOMMENDATIONS}

The following recommendations are noteworthy:

- More works should be done in the area of packaging, by developing appropriate packaging material that will protect the quality characteristics of the cookies.

- Establishing shelf life duration for the cookies, by carrying out a storage stability study.

\section{REFERENCES}

Ajibola, F. C.;Oyerinde, O. V. and Adeniyan, S. O. (2015). Physiochemical and Antioxidant Properties of Whole Wheat Biscuits Incorporated with Moringa oleifera Leaves and Cocoa Powder. Journal of Scientific Research and Report.7(3):195-206.

Aleid, S. M.; Barber, A. R.; Rettke, M.; Leo, N.;Alisenaien, W. A. and Sallam, A. A. (2012). Utilization of Modified Atmosphere Packaging to Extend the Shelf Life of Khalas Fresh Dates. Intl. Journal of Food Science Technology.47:1518-1525.

Ayo, G. O.; Ameh, U. E.;Alifah, O. N. and Babatunde, R. M. (2007). Proximal Compositions of Biscuits Produced from Wheat Flour and Maize Bran Composite Flour Fortified with Carrot Extract. Journal of Nutrition and Food Sciences. 5: 395.

Betty, T.; Jacob, A.; Faustina, D.;Wireko, M. and Elsa, I. O. (2016). Water Melon Seed as Food Nutrient Composition, Phytochemicals and Antioxidant Activity. International Journal of Nutrition and Food Science 5(2):139-144.

Boober, W. J.; Baker, J. S. and Davies, B. (2006). Development of a Biscuit: An Alternative approach to Biscuit Manufacture. Nutritional Journal5(7): 600-700.

Chinma, C. E. and Gernah, D. T. (2001). Physicochemical and Sensory Properties of Cookies Produced from Cassava/Soya Bean/Mango Composite Flours. Journal of Raw Material and Research 4:32-43.

Chukwu, M. N.; Ezeagwula, C. G.; Nwakaudu, A. A; Oti, W. and Anyaogu, I. (2019). Microbial Loads of Ogiri-Ahuekere Condiment Produced from Groundnut Seed (Arachis hypogaea Linn). Agriculture and Food Sciences Research 6(1) 114-119.

Dada, M.; Nwawe, C. N.; Okere, R. A. and Uwubanmwem, I. O. (2012) Potentials of Date Palm Tree to the Nigerian Economy. World Journal of Agricultural Science 8 (3): 309-315.

El-Adawy, T. A. and Taha, K. M. (2001). Characteristics and Consumption of Watermelon, Pumpkin and Paprika Seed Oils and Flour. Journal of Food Chemistry. 49(3): 153-159.

Erhirhie, E. O. and Ekene, N. E. (2013). Medicinal Values on Citrus lanatus (watermelon): Pharmacological Review. International Journal of Research in Pharmaceutical and Biomedical Sciences.4 (4):1305-1312.

Farheena, I.; Avanish, K. and Uzma, A. (2015). Development and Quality Evaluation of Cookies Fortified with Date Paste (Phoenix dactylifera L.). International Journal of Science and Technology3(4):160-163.
Gomez, M. I.; Obilance, A. B.; Martin, D. F.; Madzvanuse, M. and Many, E. S. (2007). Manual of Laboratory Procedure for Quality Evaluation of Sorghum and Millet. International Crop Research Institute of the Semi-Arid and Tropics (ICRSAT), India. Page 64.

Hasmadi, I. and Sandra, E. H. (2014). Effect of Fat Types on the Structural and Textural Properties of Dough and Semi-Sweet Biscuit. Journal of Food Science and Technology 51(9):1998-2005.

Hamza, A. M.; Agho C.; Ado, S. G.; Ikuenobe, C. E.;Ataga, C. D. and Odewale, J. O. (2014).Proximate compositions evaluation and variability among cultivars of date palm (Phoenixdactylifera L.) in Nigeria.International Journal of Plant and Soil Science. 3(3):248259

Ishiwu, C. N.; Nkwo, U. O.; Iwuno, J. G.;Obiegbuna, J. E. and Uchegbu, N. N. (2014). Optimization of Taste and Texture of Biscuits Produced from Blend of Plantain, Sweet Potato and Malted Sorgum Flour. African Journal of Food Sciences 8 (5): 233-238.

Kumar, P.; Yadava, R. K.; Gollen, B.; Kumar, S.; Verna, R. K. and Yadau, S. (2011). Nutritional Contents and Medicinal properties of Wheat. $A$ Review of Life Sciences and Medicine Research.20:11.

McWalter, P. P and Shetty, K. (2003). Inhibitory Effects of Rosmarinic Acid Extracts on Porcine Pancreatic Amylase. J. Clin. Nutr. 13:101106.

Miller, R. A.; Hoseney, R.C. and Morris, C.F. (1997). Effect of formula water content on the spread of sugar-snap cookies. Cereal chemistry 74(5):669-671.

Nasir, S. I. and Abufoul, A. (2004). Using Free Fat Watermelon, Citrillus vulgaris Seed Kernels in Preparing High Protein Biscuits. Page 45-54.

Olapade, A. A. and Adeyemo, A. M. (2014). Evaluation of cookies produced from blends of wheat, cassava and cowpea flours. International Journal of Food studies 3: 175-185.

Peter-Ikechukwu, A. I.; Okafor, D. R.; Kabuo, N. O.; Ibeabuchi, J. C.; Odimegwu, E.;Alagbaoso, N.;Njideka, N. E. and Mbah, R. N. (2016). Production and Evaluation of Cookies from Whole Wheat and Date Palm Fruit Pulp. Int'l Journal of Advancement in Eng. Tech. Management and Applied Science 4:1-31.

Peter-Ikechukwu, A; Osuji, C. M., Ihediohamma, N. C., Okafor, D. C. and Chukwu, M. N. (2019). Proximate composition and organoleptic characteristics of sausage rolls made from cocoyam and wheat flour enriched with soybean flour. Research Journal of Food Science and Nutrition 4(1): 1-11. https://doi.org/10.31248/RJFSN2018.057

Ubbor, S. C. and Akobundu, E. N. T. (2009). Quality Characteristics of Cookies from Composite Flours of Watermelon Seed, Cassava and Wheat. Pakistan Journal of Nutrition. 